\title{
Growing-season temperature and precipitation are independent drivers of global variation in xylem hydraulic conductivity
}

\section{Pengcheng He $\mathrm{H}^{1,2,3}$ | Sean M. Gleason ${ }^{4}$ | lan J. Wright ${ }^{5}$ | Ensheng Weng ${ }^{6}$ (D) | Hui Liu', ${ }^{1,2}$ Shidan Zhu ${ }^{7}$ Mingzhen Lu ${ }^{8}$ Q Qi Luo ${ }^{3,9}$ | Ronghua Li ${ }^{10}$ | Guilin $\mathbf{W u}^{1,2}$ | Enrong Yan $^{11}$ | Yanjun Song ${ }^{11}$ | Xiangcheng Mi $^{12}$ | Guangyou Hao ${ }^{13}$ | Peter B. Reich ${ }^{14,15}$ | Yingping Wang ${ }^{1,16}$ | David S. Ellsworth ${ }^{15}$ | Qing Ye Ye $^{1,2}$}

${ }^{1}$ Key Laboratory of Vegetation Restoration and Management of Degraded Ecosystems, and Guangdong Provincial Key Laboratory of Applied Botany, South China Botanical Garden, Chinese Academy of Sciences, Guangzhou, China

${ }^{2}$ Center for Plant Ecology, Core Botanical Gardens, Chinese Academy of Sciences, Guangzhou, China

${ }^{3}$ College of Resources and Environment, University of Chinese Academy of Sciences, Beijing, China

${ }^{4}$ USDA-ARS Water Management and Systems Research Unit, Fort Collins, CO, USA

${ }^{5}$ Department of Biological Sciences, Macquarie University, Sydney, NSW, Australia

${ }^{6}$ Center for Climate Systems Research, Columbia University, New York, NY, USA

${ }^{7}$ Guangxi Key Laboratory of Forest Ecology and Conservation, College of Forestry, Guangxi University, Nanning, China

${ }^{8}$ Department of Ecology and Evolutionary Biology, Princeton University, Princeton, NJ, USA

${ }^{9}$ Institute of Geographic Sciences and Natural Resources Research, Chinese Academy of Sciences, Beijing, China

${ }^{10}$ Institute of Tropical and Subtropical Ecology, South China Agricultural University, Guangzhou, China

${ }^{11}$ School of Ecological and Environmental Sciences, East China Normal University, Shanghai, China

${ }^{12}$ State Key Laboratory of Vegetation and Environmental Change, Institute of Botany, Chinese Academy of Sciences, Beijing, China

${ }^{13}$ Key Laboratory of Forest Ecology and Management, Institute of Applied Ecology, Chinese Academy of Sciences, Shenyang, China

${ }^{14}$ Department of Forest Resources, University of Minnesota, St. Paul, MN, USA

${ }^{15}$ Hawkesbury Institute for the Environment, Western Sydney University, Penrith, NSW, Australia

${ }^{16} \mathrm{CSIRO}$ Oceans and Atmosphere, Aspendale, Vic., Australia

\section{Correspondence}

Qing Ye, Key Laboratory of Vegetation Restoration and Management of Degraded Ecosystems, and Guangdong Provincial Key Laboratory of Applied Botany, South China Botanical Garden, Chinese Academy of Sciences, Xingke Road 723, Guangzhou 510650, China.

Email: qye@scbg.ac.cn

Funding information National Natural Science Foundation of China, Grant/Award Number: 31570405 and 31825005; Institution of South China Sea Ecology and Environmental Engineering, Chinese Academy of Sciences, Grant/Award Number: ISEE2018YB01

\begin{abstract}
Stem xylem-specific hydraulic conductivity $\left(K_{s}\right)$ represents the potential for plant water transport normalized by xylem cross section, length, and driving force. Variation in $K_{\mathrm{s}}$ has implications for plant transpiration and photosynthesis, growth and survival, and also the geographic distribution of species. Clarifying the globalscale patterns of $K_{\mathrm{S}}$ and its major drivers is needed to achieve a better understanding of how plants adapt to different environmental conditions, particularly under climate change scenarios. Here, we compiled a xylem hydraulics dataset with 1,186 speciesat-site combinations ( 975 woody species representing 146 families, from 199 sites worldwide), and investigated how $K_{\mathrm{S}}$ varied with climatic variables, plant functional types, and biomes. Growing-season temperature and growing-season precipitation drove global variation in $K_{\mathrm{S}}$ independently. Both the mean and the variation in $K_{\mathrm{S}}$ were highest in the warm and wet tropical regions, and lower in cold and dry regions,
\end{abstract}


such as tundra and desert biomes. Our results suggest that future warming and redistribution of seasonal precipitation may have a significant impact on species functional diversity, and is likely to be particularly important in regions becoming warmer or drier, such as high latitudes. This highlights an important role for $K_{\mathrm{S}}$ in predicting shifts in community composition in the face of climate change.

KEYWORDS

biome, climate, functional types, hydraulic diversity, species distribution, water transport

\section{1 | INTRODUCTION}

Climate change will likely result in a redistribution of precipitation across the Earth's surface, thus, also affecting the timing and amount of plant available water to plants and ecosystems (Pachauri et al., 2014; Putnam \& Broecker, 2017). It is possible that shifts in temperature and rainfall patterns may lead to widespread forest decline in regions where droughts are predicted to increase in duration and severity (Allen et al., 2010; Klein \& Hartmann, 2018). Quantifying physiological traits associated with water supply and drought survival (e.g., hydraulic conductivity and water potential at hydraulic dysfunction) has great potential for predicting shifts in community composition (Li et al., 2015), species' distribution (Anderegg, 2015; Fei et al., 2017), and ecosystem functioning (Myers-Smith, Thomas, \& Bjorkman, 2019).

Xylem-specific hydraulic conductivity $\left(K_{s}\right)$ represents the water transport potential of the xylem tissue. It is expressed as the rate of water transport through a given area and length of sapwood across a given pressure gradient (Sperry, Donnelly, \& Tyree, 1988). Transporting water from soil to the canopy requires an intact water column in the xylem from roots to shoots (Gleason, Butler, Ziemińska, Waryszak, \& Westoby, 2012). This process is greatly facilitated by increasing $K_{\mathrm{s}}$, and as such, $K_{\mathrm{s}}$ plays a critical role in achieving wholeplant water balance and is therefore critically linked with transpiration (Manzoni et al., 2013), photosynthesis (Ávila-Lovera, Zerpa, \& Santiago, 2017; Santiago et al., 2004; Zhu, Song, Li, \& Ye, 2013), growth (Fan, Zhang, Hao, Ferry Slik, \& Cao, 2012; Liu et al., 2019; Poorter et al., 2010), and survival (Anderegg et al., 2012, 2016). The interaction between water availability and hydraulic capacity can also strongly influence the geographic distribution of plant species (Liang et al., 2019; Nardini \& Luglio, 2014; Pockman \& Sperry, 2000).

A number of studies have examined the covariation among xylem structure, hydraulic vulnerability, xylem hydraulic efficiency, and safety from embolism (Jacobsen, Pratt, Tobin, Hacke, \& Ewers, 2012; Méndez-Alonzo, Paz, Zuluag, Rosell, \& Olson, 2012; Zanne et al., 2010), and also the correlations between these hydraulic traits and climatic variables. For instance, Zhang, Cao, Fan, and Zhang (2013) studied 316 angiosperm tree species in southwest China, and found that xylem conduit diameter was positively correlated with mean annual temperature (MAT) and precipitation (MAP). Similarly, at the global scale, Morris et al. (2018) found that mean vessel diameter was positively correlated with MAT and precipitation across 2,332 woody angiosperm species. Furthermore, xylem safety $\left(\mathrm{P}_{50}\right.$; xylem water potential resulting in $50 \%$ loss of hydraulic conductance) in stems and leaves has been found to correlate negatively with precipitation (Blackman et al., 2014; Choat et al., 2012; Li et al., 2018). Considering that $K_{\mathrm{S}}$ and its primary component, vessel diameter, are positively correlated with precipitation, and that safety is negatively correlated with precipitation, we might then reasonably expect an inverse correlation between $K_{S}$ and $P_{50}$ across species and habitats, that is, an efficiency-safety trade-off might exist among vascular plants. Although such a trade-off is often implied (e.g., Choat et al., 2012), the empirical support for it is inconsistent (Gleason et al., 2016; Zhu et al., 2013).

Two conflicting syntheses have been conducted previously to clarify regional patterns of $K_{\mathrm{s}}$. Maherali, Pockman, and Jackson (2004) investigated $K_{S}$ among 167 woody species in North Carolina and Texas, United States, and reported that $K_{\mathrm{S}}$ was higher at drier sites (lower MAP). They gave two possible reasons for this result. First, high $K_{\mathrm{S}}$ might facilitate increased transpiration under dry conditions without increasing the water potential gradient, and thus without increasing embolization risk (Maherali \& DeLucia, 2001; Mencuccini, 2003). This could be adaptive for plants in arid environments with high evaporative demand. Second, in this study, most species from arid regions were deciduous with short leaf life spans, and thus were able to avoid xylem embolization by dropping their leaves during drought, yet also maintain high $K_{\mathrm{s}}$ during times of sufficient water availability (Reich et al., 1999). More recently, Gleason, Butler, and Waryszak (2013) studied 120 angiosperm species from eight sites across a broad range of climates in eastern Australia. They found that $K_{\mathrm{S}}$ was strongly and positively correlated with summer precipitation. They suggested that natural selection in wet and high radiation habitats should favor the evolution of highly conductive xylem to achieve high levels of water transport and therefore photosynthetic income, whereas natural selection in arid habitats should favor shorter stature and lower leaf surface area to sapwood cross-sectional area ratio $\left(A_{L} / A_{S}\right)$ to maintain water balance, while at the same time avoiding hydraulic failure.

Despite these regional studies having revealed certain relationship between precipitation and $K_{\mathrm{S}}$ (yet to some extent, the results are contradictory), our understanding remains limited about how $K_{\mathrm{S}}$ 
varies across plant functional types (PFTs) and biomes, and which climatic factors drive variation in $K_{\mathrm{S}}$ at the global scale.

$K_{\mathrm{S}}$ is one of the key traits that significantly influences how water and carbon are coupled and the success of different water use strategies in different environments (Anderegg, 2015; Anderegg et al., 2012; ÁvilaLovera et al., 2017; Fan et al., 2012; Manzoni et al., 2013; Poorter et al., 2010; Santiago et al., 2004; Zhu et al., 2013). In areas with warmer temperatures and abundant soil moisture, $K_{\mathrm{S}}$ can be high in part because species must compete, so in order to preemptively use available soil moisture, fast water transport and high water use are likely selected for (Gleason et al., 2013; Morris et al., 2018). In cool, moist habitats, PET (potential evapotranspiration) is rarely high, so there is less selective advantage in having higher $K_{\mathrm{s}}$, although higher $K_{\mathrm{s}}$ would still allow for either thinner stems or less living sapwood, per unit water delivered to the canopy. In habitats with intermediate or variable temperature and PET, low $K_{\mathrm{S}}$ may be selected for to enhance survival (Anderegg et al., 2016; Petit, Anfodillo, Carraro, Grani, \& Carrer, 2011; conceptual relationship shown in Figure 1). Here, we compiled a dataset of published and unpublished $K_{\mathrm{s}}$ measurements for 975 woody species sampled from 199 sites worldwide (1,186 species-at-site combinations, in total; Figure S1a). These species and sites represent a wide range of PFTs and biomes (Figure S1b).

We sought to quantify, at the global scale:

1. Covariation in $K_{\mathrm{s}}$ with climatic variables, and in doing so, identifies key factors underpinning $K_{\mathrm{S}}$ variation. As xylogenesis is often limited by low temperatures and precipitation

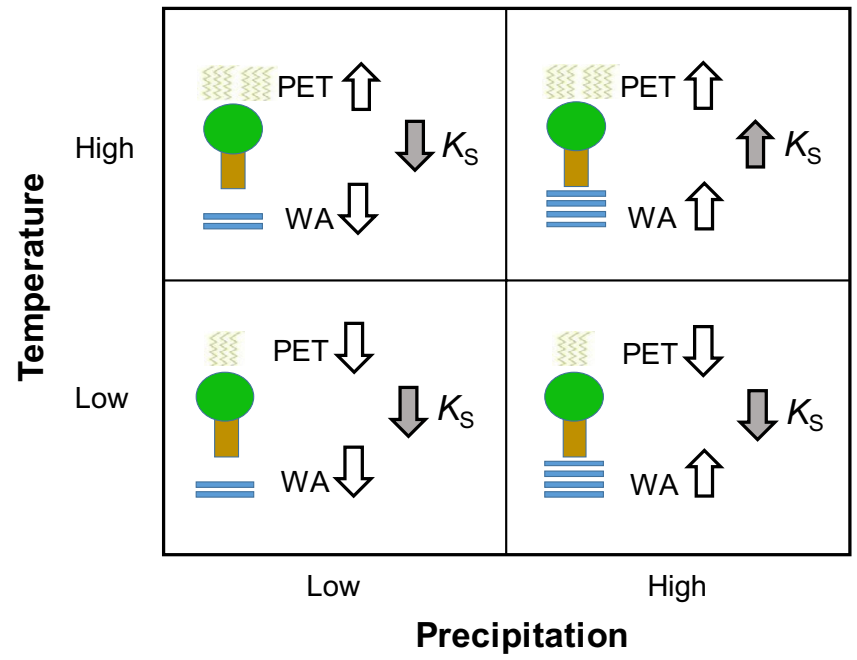

FIGURE 1 Conceptual framework for $K_{\mathrm{S}}$ under different environmental scenarios. $K_{S}$, stem xylem-specific hydraulic conductivity. $K_{S}$ is selected for in wet habitats with high PET to maintain high rates of water delivery (per unit leaf area) and to avoid decreasing xylem water potentials. In habitats with low temperatures and PET, highly conductive xylem is selected against because the driving force for water transport is reduced, and therefore, there is less selective advantage for conductive xylem. In dry habitats, low $K_{s}$ is selected for to achieve higher survival. PET, potential evapotranspiration; WA, water availability [Colour figure can be viewed at wileyonlinelibrary.com]
(Petit et al., 2011; Zhang, Gou, Manzanedo, Zhang, \& Pederson, 2018), we hypothesize that growing-season temperature $\left(T_{\mathrm{gs}}\right)$ and precipitation $\left(P_{\mathrm{gs}}\right)$ would strongly and positively affect $K_{\mathrm{s}}$.

2. Variation in $K_{S}$ across PFTs and biomes. For example, we might expect species differing markedly in xylem anatomy (e.g., angiosperms vs. gymnosperms) or in growth form (e.g., lianas vs. selfsupporting angiosperms) to exhibit different values of $K_{\mathrm{S}}$ (Apgaua et al., 2017; Bond, 1989; Chen et al., 2015, 2017; Field \& Wilson, 2012; Sperry, Hacke, \& Pittermann, 2006; van der Sande, Poorter, Schnitzer, Engelbrecht, Markesteijn, 2019). Similarly, as already discussed, we might also expect regions with marked differences precipitation and evaporative demand (e.g., hot rainforest vs. cold deserts) to favor species with different hydraulic capacities and/ or conduit diameter (Anderegg \& HilleRisLambers, 2016; Choat et al., 2012; Niu, Meinzer, \& Hao, 2017; Yuan et al., 2010).

\section{2 | MATERIALS AND METHODS}

\section{1 | Data collection}

We compiled published and unpublished $K_{\mathrm{S}}$ measurements (Data file S1). Almost half of the data came from the previously published Xylem Functional Traits Database (XFT; Choat et al., 2012; Gleason et al., 2016), which can be accessed from the TRY Plant Traits Database (https://www.try-db.org/TryWeb/Home.php; Kattge et al., 2011). We also conducted searches on Web of Science, Google Scholar, and China National Knowledge Infrastructure (http://www.cnki.net) using the keywords "xylem hydraulic conductivity," "branch/stem hydraulic conductivity," "water conductivity," and "hydraulic traits." To minimize ontogenetic and methodological variation, we included data that met the following criteria: (a) wild plants growing in natural ecosystems, excluding greenhouse and common garden experiments; (b) xylem hydraulic conductivity measured on terminal stem or branch segments (commonly $3-10 \mathrm{~mm}$ in diameter and $10-30 \mathrm{~cm}$ in length), that is, measurements on root or leaf tissues were not included; (c) measurements were made on adult plants or saplings, but not on seedlings; (d) $K_{\mathrm{S}}$ was measured (e.g., Sperry et al., 1988), not estimated from vessel measurements (e.g., Hagen-Poiseuille equation); and (e) only maximum hydraulic conductivity was used, not so-called "native" hydraulic conductivity. Mean $K_{\mathrm{S}}$ values were calculated for each species at the same site (Shao et al., 2019; Wright et al., 2004, 2005).

Based on information in source publications and online floras (e.g., http://frps.eflora.cn/), species were coded into the following PFTs: liana, conifer, evergreen angiosperm tree, deciduous angiosperm tree, evergreen angiosperm shrub, and deciduous angiosperm shrub. Sites were assigned to biomes: tropical rainforest, tropical savanna, tropical deciduous forest, subtropical monsoon forest, temperate deciduous forest, semiarid woodland plus shrubland, boreal tundra, and desert.

Climate data were taken from the original reports, where available, otherwise variables such as mean annual and monthly precipitation, temperature, solar radiation, the minimum temperature of coldest month $\left(T_{\mathrm{cm}}\right)$, and precipitation of driest month $\left(P_{\mathrm{dm}}\right)$ were 
extracted from the WorldClim version 2 (http://worldclim.org/ version2; Fick \& Hijmans, 2017). When elevation data from the WorldClim database did not match elevations from published reports, temperature was scaled to match published elevation using a lapse rate of $6.0^{\circ} \mathrm{C} \mathrm{km}^{-1}$ increase in elevation. The data of annual and monthly PET were extracted from the CGIAR-CSI consortium (http://www.cgiar-csi.org/data; Zomer, Trabucco, Bossio, \& Verchot, 2008). Aridity index (whether monthly or annual) is the ratio of precipitation to PET. Variation of aridity index is calculated using coefficient of variation of the annual aridity index of recent 50 years (1966-2015) extracted from the SPEI data (http://spei.csic.es/datab ase.html; Beguería, Vicente-Serrano, Reig, \& Latorre, 2014). The data of monthly vapor pressure deficit (VPD) were extracted from the TerraClimate dataset (http://www.climatologylab.org/terraclima te.html; Abatzoglou, Dobrowski, Parks, \& Hegewisch, 2018). We defined the growing season as being the set of consecutive months that satisfied the conditions: (a) monthly mean temperature $\geq 5^{\circ} \mathrm{C}$, and (b) monthly precipitation/PET $\geq 0.05$ (Wright et al., 2017).

\subsection{Data analysis}

Data were first $\log _{10}$-transformed to attain approximate normality (Kerkhoff \& Enquist, 2009), except for temperature and solar radiation data. Relationships between $K_{\mathrm{S}}$ and environmental variables were characterized using Pearson correlation and linear regression. One-way analysis of variance (ANOVA) with least significant difference was used to test for differences in mean $K_{S}$ for species grouped into PFTs and biomes. Multiple regression and stepwise regression analyses were conducted to estimate predictive equations for $K_{\mathrm{s}}$, and an ANOVA was combined into a linear contrast (regression; Hector et al., 1999). Quadratic regression was used to evaluate the relationship between $K_{\mathrm{S}}$ and latitude. $p<.05$ was used to determine the significant level for all the above models. All analyses were run in R software (version 3.5.0, R Core Team, 2018).

\section{3 | RESULTS}

Our synthesis of $K_{\mathrm{S}}$ from 199 sites around the world showed that $T_{\text {gs }}$ (Figure $2 \mathrm{a}$ ) and $P_{\mathrm{gs}}$ (Figure $2 \mathrm{~b}$ ) explained $21.3 \%$ and $12.3 \%$ of the global variation in $K_{\mathrm{s}}$, respectively, for example, higher $K_{\mathrm{s}}$ at warmer and/or wetter sites (Figures S1c and S2). $T_{\mathrm{cm}}$ explained $11.7 \%$ of the variation in $K_{\mathrm{S}}$ (Table S1). Several other climatic variables such as solar radiation, aridity index, VPD, and $P_{\mathrm{dm}}$ explained relatively smaller portions of variation in $K_{\mathrm{S}}$ than $T_{\mathrm{gs}}$ or $P_{\text {gs }}$ (Table S1).

$K_{\mathrm{S}}$ increased independently with both $T_{\mathrm{gs}}$ and $P_{\mathrm{gs}}\left(R^{2}=.22\right.$; Figure 3; the interaction between $T_{\mathrm{gs}}$ and $P_{\mathrm{gs}}$ was clearly nonsignificant, $p=.756$ ). Regression models using all climate variables explained up to $32 \%$ variation in $K_{s}$, and a subset identified in a stepwise process explained $28 \%$ variation in $K_{\mathrm{S}}$. Regression models using
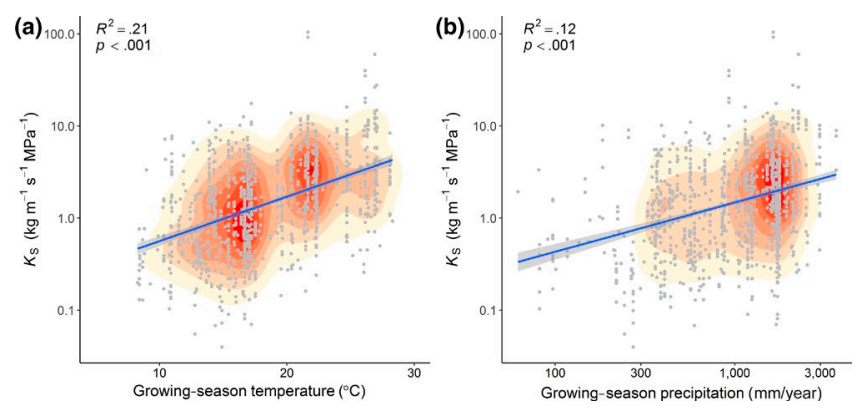

FIGURE 2 Global variation in $K_{S}$ in relation to climate: global variation in $K_{S}$ in relation to growing-season temperature (a) and growing-season precipitation (b). Colors indicate the density of points from highest density (red) to lowest (yellow). Solid lines represent fitted ordinary least squares regression models with 95th confidence intervals. $K_{\mathrm{s}}$, stem xylem-specific hydraulic conductivity $\left(\mathrm{kg} \mathrm{m}^{-1} \mathrm{~s}^{-1} \mathrm{MPa}^{-1}\right)$. OLS, ordinary least squares [Colour figure can be viewed at wileyonlinelibrary.com]

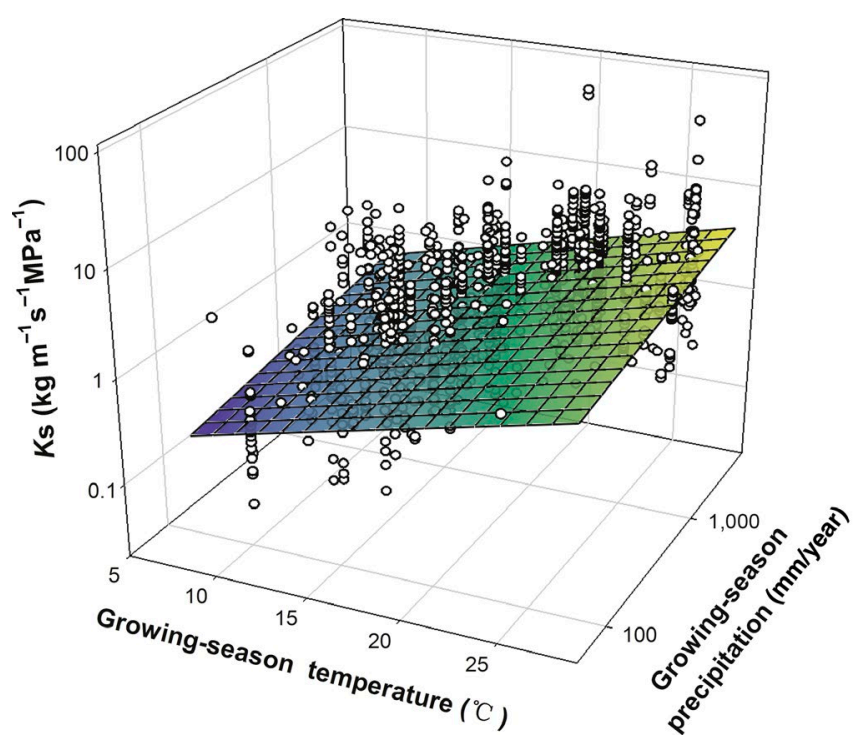

FIGURE 3 Global variation in $K_{\mathrm{s}}$ in relation to $T_{\mathrm{gs}}$ and $P_{\mathrm{gs}}$. The best-fit function estimated by multiple linear regression was $\log K_{\mathrm{s}}=0.14 \log P_{\mathrm{gs}}+0.04 T_{\mathrm{gs}}-1.04$ (all parameters $p<.01$; $\left.R^{2}=.22\right) . K_{\mathrm{S}}$, stem xylem-specific hydraulic conductivity $\left(\mathrm{kg} \mathrm{m}^{-1} \mathrm{~s}^{-1} \mathrm{MPa}^{-1}\right) ; P_{\mathrm{gs}}$, growing-season precipitation (mm); $T_{\mathrm{gs}}$, growing-season temperature $\left({ }^{\circ} \mathrm{C}\right)$ [Colour figure can be viewed at wileyonlinelibrary.com]

all climatic variables, PFTs, and biomes explained up to $41 \%$ variation in $K_{\mathrm{S}}$ (Table S2). $K_{\mathrm{S}}$ differed significantly between PFTs ( $F=26.0$, $p<.0001)$ and biomes $(F=6.0, p<.0001)$, and was mostly influenced by $T_{\mathrm{gs}}(F=397.4, p<.0001$; Table S3).

On average, lianas had higher $K_{\mathrm{S}}\left(14.43 \mathrm{~kg} \mathrm{~m}^{-1} \mathrm{~s}^{-1} \mathrm{MPa}^{-1}\right)$ than other PFTs (Figure 4A; Table S4). Deciduous trees and evergreen trees had similar mean values of $K_{\mathrm{S}}\left(3.06 \mathrm{~kg} \mathrm{~m}^{-1} \mathrm{~s}^{-1} \mathrm{MPa}^{-1}\right.$ and $2.71 \mathrm{~kg} \mathrm{~m}^{-1} \mathrm{~s}^{-1} \mathrm{MPa}^{-1}$, respectively; Table S4). Evergreen shrubs had lower $K_{\mathrm{S}}$ than those of deciduous shrubs. Conifers had the lowest mean value of $K_{\mathrm{S}}\left(0.95 \mathrm{~kg} \mathrm{~m}^{-1} \mathrm{~s}^{-1} \mathrm{MPa}^{-1}\right)$. Additionally, the variance in $K_{\mathrm{S}}$ was lowest among conifers and evergreen shrubs, but highest among lianas (Figure 4B; Figure S4). 

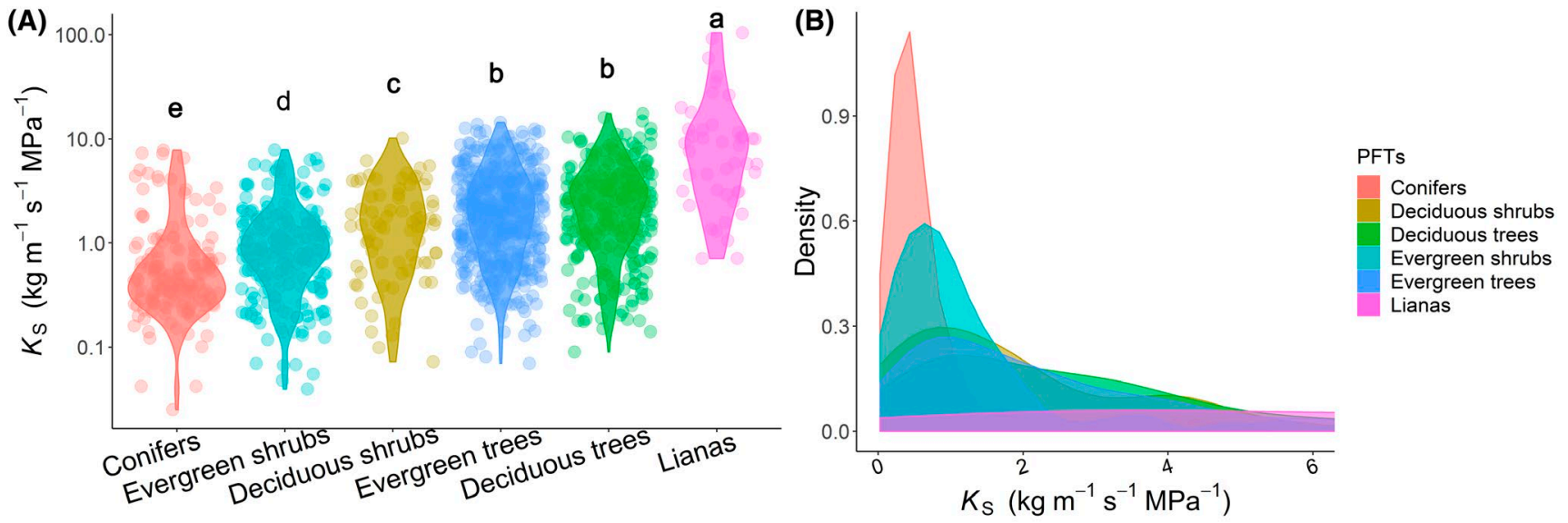

FIGURE 4 Patterns of $K_{\mathrm{S}}$ across PFTs: (A) Differences in $K_{\mathrm{S}}$ among PFTs. Significant differences $(p<.05)$ among PFTs are indicated by different lowercase letters (a-e). (B) Density distribution of $K_{s}$ among PFTs. $K_{s}$, stem xylem-specific hydraulic conductivity $\left(\mathrm{kg} \mathrm{m}^{-1} \mathrm{~s}^{-1} \mathrm{MPa}^{-1}\right)$. $\mathrm{PFT}$, plant functional types [Colour figure can be viewed at wileyonlinelibrary.com]
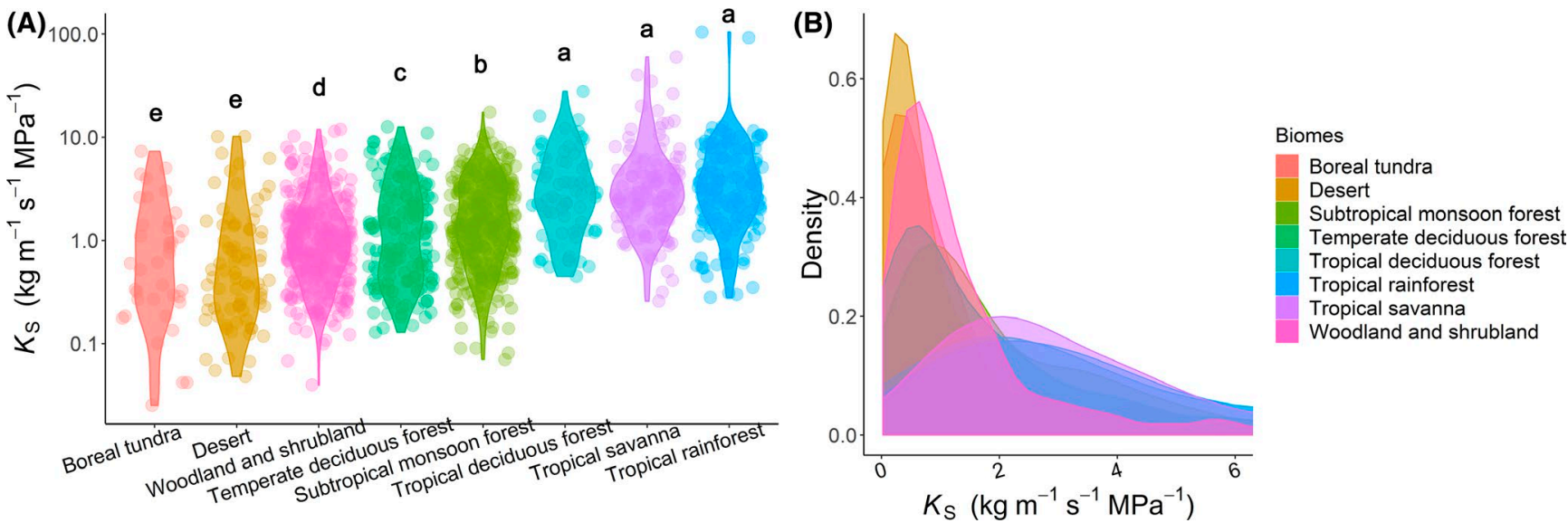

FIGURE 5 Patterns of $K_{\mathrm{S}}$ across biomes: (A) Differences in $K_{\mathrm{S}}$ among plant biomes. Significant differences $(p<.05)$ among biomes are indicated by different lowercase letters (a-e). (B) Density distribution of $K_{\mathrm{S}}$ among plant biomes. $K_{\mathrm{S}}$, stem xylem-specific hydraulic conductivity $\left(\mathrm{kg} \mathrm{m}^{-1} \mathrm{~s}^{-1} \mathrm{MPa}^{-1}\right)$ [Colour figure can be viewed at wileyonlinelibrary.com]

Considering plant biomes, tropical rainforest species had the highest $\mathrm{K}_{\mathrm{S}}\left(5.29 \mathrm{~kg} \mathrm{~m}^{-1} \mathrm{~s}^{-1} \mathrm{MPa}^{-1}\right.$; Figure 5A; Table S5), and boreal tundra and desert species had the lowest $\left(1.25 \mathrm{~kg} \mathrm{~m}^{-1} \mathrm{~s}^{-1} \mathrm{MPa}^{-1}\right.$ and $1.28 \mathrm{~kg} \mathrm{~m}^{-1} \mathrm{~s}^{-1} \mathrm{MPa}^{-1}$, respectively). Interestingly, the variance in $K_{\mathrm{S}}$ increased from biomes with low temperature (e.g., boreal tundra) or low precipitation (e.g., desert) to biomes with high temperature and high precipitation (e.g., tropical rainforests; Figure 5B; Figure S5).

\section{4 | DISCUSSION}

In this study, we analyzed the global patterns of plant $K_{S}$, including how this trait differs among PFTs and biomes, and its coordination with climatic variables, thus providing new insights into how climate affects plant water use and the evolution of plant water use strategies.

Our results showed that air temperature was a more significant explanatory variable than precipitation, but both temperature and precipitation were influential. Moreover, species from warm regions (e.g., tropical rainforests and tropical savannas) had relatively high $K_{\mathrm{s}}$, whereas species in cold regions (e.g., boreal tundra and woodland plus shrubland) had relatively low $K_{\mathrm{s}}$. There are three possible interpretations for these results: first, plants in warm habitats tend to have high transpiration rates (Yuan et al., 2010), supported by high $K_{\mathrm{s}}$, to avoid overheating during warm periods (Wright et al., 2017). In contrast, in cold sites such as tundra and woodland/shrubland, PET is never high, so there is less selective advantage in having higher $K_{\mathrm{S}}$. Second, species at warm sites need to compete for light and grow fast, and thus, require high photosynthetic rates and high water transport capacity (Apgaua et al., 2017; Chen et al., 2015; Fan et al., 2012). Third, there is a benefit of small conduits for resistance to embolism arising from the freezing and thawing of sap (Feild \& Brodribb, 2001; Pittermann \& Sperry, 2003), and small conduits are usually associated with low $K_{S}$ (Morris et al., 2018). In contrast, high $K_{\mathrm{S}}$ achieved via wide conduits has a greater risk of embolism arising from freeze-thaw cycles (Mayr, Rothart, \& Dämon, 2003; Niu et al., 2017). 
We found $K_{\mathrm{S}}$ was high at high rainfall sites, which is consistent with Gleason et al. (2013), suggesting that differences in $K_{\mathrm{S}}$ between wet and dry climates reflect the competing requirements among water transport, embolism, and maintenance cost per unit water transported through the vasculature. As such, we might expect high $K_{\mathrm{S}}$ to confer a fitness advantage in habitats with low risk of embolism and high potential for $\mathrm{CO}_{2}$ assimilation, whereas low $\mathrm{K}_{\mathrm{S}}$ to confer a fitness advantage in shaded and/or arid environments where there is a meaningful risk of hydraulic failure and/or high requirement for low xylem construction and maintenance costs. Although this idea may account for the evolution of highly conductive xylem in high-rainfall habitats, it does not provide a satisfying explanation for why low $K_{\mathrm{s}}$ should arise in arid or shaded habitats. This is because, even in these habitats, higher $K_{\mathrm{S}}$ should confer either greater water transport per unit cross-sectional investment or confer less cross-sectional investment per unit water transport (i.e., thinner stems or less living sapwood). Only in the case where higher $K_{\mathrm{S}}$ results in compromised mechanical stability (but see Zanne et al., 2010), increased susceptibility to drought or cold weather injury, or a significant carbon expenditure (amortized over the lifetime of the plant), should natural selection favor the evolution of low $K_{\mathrm{s}}$.

Compared to MAT and precipitation, we found that mean temperature and precipitation over the growing season alone explained more variance in $K_{\mathrm{S}}$ (Figure 2; Figure S3a,b), indicating the important role of growing season in mediating the variation in $K_{\mathrm{S}}$. One possible interpretation of this result is that xylogenesis takes place mainly during the growing season. Therefore, excessive cold or dry conditions during growing season may adversely affect xylem growth and limit the number and size of xylem elements (Petit et al., 2011; Zhang et al., 2018).

We noted that the minimum temperature of coldest month explained $11.7 \%$ of the variation in $K_{\mathrm{s}}$, suggesting that markedly cold temperatures may affect the water transport capacity of plant xylem, despite relatively less significant as compared to the effect of growing-season temperature (explained 21.3\%). These findings are consistent with the freezing tolerance hypothesis, that is, the frequency of freezing temperatures is an important climatic factor in determining large-scale patterns of species richness and distribution (Sakai \& Weiser, 1973; Wang, Fang, Tang, \& Lin, 2010; Woodward, 1990). According to the freeze-thaw-induced embolism theory, gas bubbles are formed in conduits upon freezing and expand when the sap thaws, but importantly, bubble size is limited by the width of the conduits in which the bubbles form. Thus, the formation, ultimate size of bubbles, and the subsequent spread of gas from conduit to conduit may result in damage to the water transport vasculature (Charrier et al., 2014; Mayr, Cochard, Améglio, \& Kikuta, 2007; Mayr \& Sperry, 2010). Considering that larger bubbles are more likely to form in wider conduits, species exhibiting wider conduits (and higher $K_{\mathrm{s}}$ ) may be more susceptible to freeze-thaw embolism (Davis, Sperry, \& Hacke, 1999; Pittermann \& Sperry, 2003, 2006).

Although our models provide a measure of the alignment between $K_{\mathrm{S}}$ and temperature/precipitation, most of the variation in these models remains unexplained. We acknowledge some uncertainties and limitations in our data. First, construction and maintenance costs of xylem are largely unknown. Plant vasculature appears to conform with Murray's law and similar hydraulic models (Gleason et al., 2018; McCulloh, Sperry, \& Adler, 2003; McCulloh, Sperry, Meinzer, Lachenbruch, \& Atala, 2009), that is, xylem has been designed to achieve maximum conductance for a given investment in carbon and energy. It is unlikely that vasculature would align with Murray's law if xylem costs were negligible. As such, it is possible that the construction and maintenance costs associated with efficient xylem have been underestimated. Second, it should be noted that our results are based on observations of plants at the biome and PFT levels under present climate conditions. Whether the observed sensitivities to temperature and precipitation are influenced mainly by phenotypical variation within the same species or by genotypic variation across species would likely influence the distribution of species in the future under climate change (Anderegg, 2015; Anderegg et al., 2018; Osnas et al., 2018; Pfautsch et al., 2016). If phenotypical variation dominates, climate change would likely be less impactful on species distributions than if genotypic variation was dominant. This warrants further investigation in the future. Third, much of the variation in $K_{\mathrm{S}}$ exists within sites, rather than across climate gradients. It is clear that species occurring in cold or dry habitats always have low $K_{s}$, whereas species occurring in warm and wet habitats exhibit the entire range of $K_{\mathrm{s}}$. As such, it appears that high $K_{\mathrm{S}}$ can only occur in warm and wet habitats, and this is clearly a temperature/precipitation effect, but the reason for why most species in warm and wet habitats do not achieve high $K_{\mathrm{S}}$ remains an important and interesting research question.

This work represents an important step toward a better understanding of geographic variation in plant hydraulic strategies, and builds toward a more reliable conceptual model of global vegetation functioning and the risks of climate change. In particular, $K_{\mathrm{S}}$ is an important parameter in plant hydraulic models and is used to simulate root water uptake, leaf water stress, plant carbon-water trade-offs, and mortality (Kennedy et al., 2019; Xu, Medvigy, Powers, Becknell, \& Guan, 2016). A better understanding at the biome level could inform these models and improve the representation of physiological processes, and thus, improve future simulations of vegetation structure and carbon dynamics. Our data support the continued development and improvement of process-based global vegetation models that explicitly link $K_{\mathrm{S}}$ to performance, such as plant growth, death, and dispersal (Prentice et al., 2007; Zhou, Duursma, Medlyn, Kelly, \& Prentice, 2013). We suggest that the continued measurement and inclusion of important plant hydraulic traits in these modeling efforts will improve our understanding of species-climate linkages as well as our ability to predict demographic shifts in the face of climate change.

\section{ACKNOWLEDGEMENTS}

We are grateful to the editor and reviewers for their constructive suggestions and comments on an earlier version of this manuscript. We thank Brendan Choat for his suggestions on data collection, Megan K. Bartlett and Yusuke Onoda for their comments on the manuscript, and Zeqing Ma for his suggestions on figure presentation. We also 
thank Xiaojuan Liu and Shaowei Jiang for their data contribution. This work was funded by the National Natural Science Foundation of China (31825005 and 31570405), and the Institution of South China Sea Ecology and Environmental Engineering, Chinese Academy of Sciences (ISEE2018YB01). The authors declare no conflict of interest.

\section{AUTHOR CONTRIBUTIONS}

P.H. and Q.Y. designed the study and wrote the initial manuscript. P.H. collected and analyzed the data, with help from I.J.W. P.H., S.Z., and R.L. performed trait measurements across 188 species at five study sites in China. S.M.G., Q.L., G.W., E.Y., Y.S., X.M., and G.H. contributed to the data collection. I.J.W., S.M.G., E.W., H.L., S.Z., M.L., G.H, P.B.R., Y.P.W., and D.S.E. contributed to improving the manuscript.

\section{DATA AVAILABILITY STATEMENT}

The data that support the findings of this study are available in the supplementary material of this article.

\section{ORCID}

Ensheng Weng (iD https://orcid.org/0000-0002-1858-4847

Qing Ye (iD https://orcid.org/0000-0001-5445-0996

\section{REFERENCES}

Abatzoglou, J. T., Dobrowski, S. Z., Parks, S. A., \& Hegewisch, K. C. (2018). TerraClimate, a high-resolution global dataset of monthly climate and climatic water balance from 1958-2015. Scientific Data, 5 , 1958-2015. https://doi.org/10.1038/sdata.2017.191

Allen, C. D., Macalady, A. K., Chenchouni, H., Bachelet, D., McDowell, N., Vennetier, M., ... Cobb, N. (2010). A global overview of drought and heat-induced tree mortality reveals emerging climate change risks for forests. Forest Ecology and Management, 259(4), 660-684. https:// doi.org/10.1016/j.foreco.2009.09.001

Anderegg, L. D., Berner, L. T., Badgley, G., Sethi, M. L., Law, B. E., \& HilleRisLambers, J. (2018). Within-species patterns challenge our understanding of the leaf economics spectrum. Ecology Letters, 21(5), 734-744. https://doi.org/10.1111/ele.12945

Anderegg, L. D., \& HilleRisLambers, J. (2016). Drought stress limits the geographic ranges of two tree species via different physiological mechanisms. Global Change Biology, 22(3), 1029-1045. https://doi. org/10.1111/gcb.13148

Anderegg, W. R. (2015). Spatial and temporal variation in plant hydraulic traits and their relevance for climate change impacts on vegetation. New Phytologist, 205(3), 1008-1014. https://doi.org/10.1111/ nph.12907

Anderegg, W. R., Berry, J. A., Smith, D. D., Sperry, J. S., Anderegg, L. D., \& Field, C. B. (2012). The roles of hydraulic and carbon stress in a widespread climate-induced forest die-off. Proceedings of the National Academy of Sciences of the United States of America, 109(1), 233-237. https://doi.org/10.1073/pnas.1107891109

Anderegg, W. R., Klein, T., Bartlett, M., Sack, L., Pellegrini, A. F., Choat, B., $\&$ Jansen, S. (2016). Meta-analysis reveals that hydraulic traits explain cross-species patterns of drought-induced tree mortality across the globe. Proceedings of the National Academy of Sciences of the United States of America, 113(18), 5024-5029. https://doi.org/10.1073/ pnas.1525678113

Apgaua, D. M., Tng, D. Y., Cernusak, L. A., Cheesman, A. W., Santos, R. M., Edwards, W. J., \& Laurance, S. G. (2017). Plant functional groups within a tropical forest exhibit different wood functional anatomy. Functional Ecology, 31(3), 582-591. https://doi. org/10.1111/1365-2435.12787

Ávila-Lovera, E., Zerpa, A. J., \& Santiago, L. S. (2017). Stem photosynthesis and hydraulics are coordinated in desert plant species. New Phytologist, 216(4), 1119-1129. https://doi.org/10.1111/nph.14737

Beguería, S., Vicente-Serrano, S. M., Reig, F., \& Latorre, B. (2014). Standardized precipitation evapotranspiration index (SPEI) revisited: Parameter fitting, evapotranspiration models, tools, datasets and drought monitoring. International Journal of Climatology, 34(10), 3001-3023. https://doi.org/10.1002/joc.3887

Blackman, C. J., Gleason, S. M., Chang, Y., Cook, A. M., Laws, C., \& Westoby, M. (2014). Leaf hydraulic vulnerability to drought is linked to site water availability across a broad range of species and climates. Annals of Botany, 114(3), 435-440. https://doi.org/10.1093/aob/ mcu131

Bond, W. J. (1989). The tortoise and the hare: Ecology of angiosperm dominance and gymnosperm persistence. Biological Journal of the Linnean Society, 36(3), 227-249. https://doi.org/10.1111/j.1095-8312.1989. tb00492.x

Charrier, G., Charra-Vaskou, K., Kasuga, J., Cochard, H., Mayr, S., \& Améglio, T. (2014). Freeze-thaw stress: Effects of temperature on hydraulic conductivity and ultrasonic activity in ten woody angiosperms. Plant Physiology, 164(2), 992-998. https://doi.org/10.1104/ pp.113.228403

Chen, Y. J., Cao, K. F., Schnitzer, S. A., Fan, Z. X., Zhang, J. L., \& Bongers, F. (2015). Water-use advantage for lianas over trees in tropical seasonal forests. New Phytologist, 205(1), 128-136. https://doi.org/10.1111/ nph.13036

Chen, Y.-J., Schnitzer, S. A., Zhang, Y.-J., Fan, Z.-X., Goldstein, G., Tomlinson, K. W., ... Cao, K.-F. (2017). Physiological regulation and efficient xylem water transport regulate diurnal water and carbon balances of tropical lianas. Functional Ecology, 31(2), 306-317. https ://doi.org/10.1111/1365-2435.12724

Choat, B., Jansen, S., Brodribb, T. J., Cochard, H., Delzon, S., Bhaskar, R., ... Zanne, A. E. (2012). Global convergence in the vulnerability of forests to drought. Nature, 491(7426), 752-755. https://doi. org/10.1038/nature11688

Davis, S. D., Sperry, J. S., \& Hacke, U. G. (1999). The relationship between xylem conduit diameter and cavitation caused by freezing. American Journal of Botany, 86(10), 1367-1372. https://doi. org/10.2307/2656919

Fan, Z. X., Zhang, S. B., Hao, G. Y., Ferry Slik, J. W., \& Cao, K. F. (2012). Hydraulic conductivity traits predict growth rates and adult stature of 40 Asian tropical tree species better than wood density. Journal of Ecology, 100(3), 732-741. https://doi.org/10.1111/ j.1365-2745.2011.01939.x

Fei, S., Desprez, J. M., Potter, K. M., Jo, I., Knott, J. A., \& Oswalt, C. M. (2017). Divergence of species responses to climate change. Science Advances, 3(5), e1603055. https://doi.org/10.1126/sciadv. 1603055

Feild, T. S., \& Brodribb, T. (2001). Stem water transport and freeze-thaw xylem embolism in conifers and angiosperms in a Tasmanian treeline heath. Oecologia, 127(3), 314-320. https://doi.org/10.1007/s0044 20000603

Feild, T. S., \& Wilson, J. P. (2012). Evolutionary voyage of angiosperm vessel structure-function and its significance for early angiosperm success. International Journal of Plant Sciences, 173(6), 596-609. https ://doi.org/10.1086/666099

Fick, S. E., \& Hijmans, R. J. (2017). WorldClim 2: New 1-km spatial resolution climate surfaces for global land areas. International Journal of Climatology, 37(12), 4302-4315. https://doi.org/10.1002/joc.5086

Gleason, S. M., Blackman, C. J., Gleason, S. T., McCulloh, K. A., Ocheltree, T. W., \& Westoby, M. (2018). Vessel scaling in evergreen angiosperm leaves conforms with Murray's law and area-filling assumptions: Implications for plant size, leaf size and cold tolerance. 
New Phytologist, 218(4), 1360-1370. https://doi.org/10.1111/nph. 15116

Gleason, S. M., Butler, D. W., \& Waryszak, P. (2013). Shifts in leaf and stem hydraulic traits across aridity gradients in eastern Australia. International Journal of Plant Sciences, 174(9), 1292-1301. https://doi. org/10.1086/673239

Gleason, S. M., Butler, D. W., Ziemińska, K., Waryszak, P., \& Westoby, M. (2012). Stem xylem conductivity is key to plant water balance across Australian angiosperm species. Functional Ecology, 26(2), 343-352. https://doi.org/10.1111/j.1365-2435.2012.01962.x

Gleason, S. M., Westoby, M., Jansen, S., Choat, B., Hacke, U. G., Pratt, R. B., ... Zanne, A. E. (2016). Weak tradeoff between xylem safety and xylem-specific hydraulic efficiency across the world's woody plant species. New Phytologist, 209(1), 123-136. https://doi.org/10.1111/ nph.13646

Hector, A., Schmid, B., Beierkuhnlein, C., Caldeira, M. C., Diemer, M., Dimitrakopoulos, P. G., ... Harris, R. (1999). Plant diversity and productivity experiments in European grasslands. Science, 286(5442), 1123-1127.

Jacobsen, A. L., Pratt, R. B., Tobin, M. F., Hacke, U. G., \& Ewers, F. W. (2012). A global analysis of xylem vessel length in woody plants. American Journal of Botany, 99(10), 1583-1591. https://doi.org/ 10.3732/ajb.1200140

Kattge, J., Díaz, S., Lavorel, S., Prentice, I. C., Leadley, P., Bönisch, G., ... Wirth, C. (2011). TRY - A global database of plant traits. Global ChangeBiology, 17(9),2905-2935.https://doi.org/10.1111/j.1365-2486. 2011.02451.x

Kennedy, D., Swenson, S., Oleson, K. W., Lawrence, D. M., Fisher, R., Lola da Costa, A. C., \& Gentine, P. (2019). Implementing plant hydraulics in the community land model, version 5. Journal of Advances in Modeling Earth Systems, 11(2), 485-513. https://doi.org/10.1029/2018M S001500

Kerkhoff, A. J., \& Enquist, B. (2009). Multiplicative by nature: Why logarithmic transformation is necessary in allometry. Journal of Theoretical Biology, 257(3), 519-521. https://doi.org/10.1016/j.jtbi. 2008.12.026

Klein, T., \& Hartmann, H. (2018). Climate change drives tree mortality. Science, 362(6416), 758. https://doi.org/10.1126/science.aav6508

Li, R., Zhu, S., Chen, H. Y. H., John, R., Zhou, G., Zhang, D., ... Ye, Q. (2015). Are functional traits a good predictor of global change impacts on tree species abundance dynamics in a subtropical forest? Ecology Letters, 18(11), 1181-1189. https://doi.org/10.1111/ele.12497

Li, X., Blackman, C. J., Choat, B., Duursma, R. A., Rymer, P. D., Medlyn, B. E., \& Tissue, D. T. (2018). Tree hydraulic traits are coordinated and strongly linked to climate-of-origin across a rainfall gradient. Plant, Cell \& Environment, 41(3), 646-660. https://doi.org/10.1111/ pce.13129

Liang, X., He, P., Liu, H., Zhu, S., Uyehara, I. K., Hou, H., ... Ye, Q. (2019). Precipitation has dominant influences on the variation of plant hydraulics of the native Castanopsis fargesii (Fagaceae) in subtropical China. Agricultural and Forest Meteorology, 271, 83-91. https://doi. org/10.1016/j.agrformet.2019.02.043

Liu, H., Gleason, S. M., Hao, G., Hua, L., He, P., Goldstein, G., \& Ye, Q. (2019). Hydraulic traits are coordinated with maximum plant height at the global scale. Science Advances, 5(2), eaav1332. https://doi. org/10.1126/sciadv.aav1332

Maherali, H., \& DeLucia, E. H. (2001). Influence of climate-driven shifts in biomass allocation on water transport and storage in ponderosa pine. Oecologia, 129(4), 481-491. https://doi.org/10.1007/s0044 20100758

Maherali, H., Pockman, W. T., \& Jackson, R. B. (2004). Adaptive variation in the vulnerability of woody plants to xylem cavitation. Ecology, 85(8), 2184-2199. https://doi.org/10.1890/02-0538

Manzoni, S., Vico, G., Katul, G., Palmroth, S., Jackson, R. B., \& Porporato, A. (2013). Hydraulic limits on maximum plant transpiration and the emergence of the safety-efficiency trade-off. New Phytologist, 198(1), 169-178. https://doi.org/10.1111/nph.12126

Mayr, S., Cochard, H., Améglio, T., \& Kikuta, S. B. (2007). Embolism formation during freezing in the wood of Picea abies. Plant Physiology, 143(1), 60-67.

Mayr, S., Rothart, B., \& Dämon, B. (2003). Hydraulic efficiency and safety of leader shoots and twigs in Norway spruce growing at the alpine timberline. Journal of Experimental Botany, 54(392), 2563-2568. https://doi.org/10.1093/jxb/erg272

Mayr, S., \& Sperry, J. S. (2010). Freeze-thaw-induced embolism in Pinuscontorta: Centrifuge experiments validate the 'thaw-expansion hypothesis' but conflict with ultrasonic emission data. New Phytologist, 185(4), 1016-1024. https://doi.org/10.1111/j.1469-8137.2009.03133.x

McCulloh, K. A., Sperry, J. S., \& Adler, F. R. (2003). Water transport in plants obeys Murray's law. Nature, 421(6926), 939. https://doi. org/10.1038/nature01444

McCulloh, K. A., Sperry, J. S., Meinzer, F. C., Lachenbruch, B., \& Atala, C. (2009). Murray's law, the 'Yarrum' optimum, and the hydraulic architecture of compound leaves. New Phytologist, 184(1), 234-244.

Mencuccini, M. (2003). The ecological significance of long-distance water transport: Short-term regulation, long-term acclimation and the hydraulic costs of stature across plant life forms. Plant, Cell \& Environment, 26(1), 163-182. https://doi.org/10.1046/j.1365-3040.2003.00991.x

Méndez-Alonzo, R., Paz, H., Zuluaga, R. C., Rosell, J. A., \& Olson, M. E. (2012). Coordinated evolution of leaf and stem economics in tropical dry forest trees. Ecology, 93(11), 2397-2406. https://doi. org/10.1890/11-1213.1

Morris, H., Gillingham, M. A. F., Plavcová, L., Gleason, S. M., Olson, M. E., Coomes, D. A., ... Jansen, S. (2018). Vessel diameter is related to amount and spatial arrangement of axial parenchyma in woody angiosperms. Plant, Cell \& Environment, 41(1), 245-260. https://doi. org/10.1111/pce.13091

Myers-Smith, I. H., Thomas, H. J., \& Bjorkman, A. D. (2019). Plant traits inform predictions of tundra responses to global change. New Phytologist, 221(4), 1742-1748. https://doi.org/10.1111/nph.15592

Nardini, A., \& Luglio, J. (2014). Leaf hydraulic capacity and drought vulnerability: Possible trade-offs and correlations with climate across three major biomes. Functional Ecology, 28(4), 810-818. https://doi. org/10.1111/1365-2435.12246

Niu, C. Y., Meinzer, F. C., \& Hao, G. Y. (2017). Divergence in strategies for coping with winter embolism among co-occurring temperate tree species: The role of positive xylem pressure, wood type and tree stature. Functional Ecology, 31(8), 1550-1560. https://doi. org/10.1111/1365-2435.12868

Osnas, J. L. D., Katabuchi, M., Kitajima, K., Wright, S. J., Reich, P. B., Van Bael, S. A., ... Lichstein, J. W. (2018). Divergent drivers of leaf trait variation within species, among species, and among functional groups. Proceedings of the National Academy of Sciences of the United States of America, 115(21), 5480-5485. https://doi.org/10.1073/ pnas.1803989115

Pachauri, R. K., Allen, M. R., Barros, V. R., Broome, J., Cramer, W., Christ, R., \& Dubash, N. K. (2014). Climate change 2014: Synthesis report. Contribution of working groups I, II and III to the fifth assessment report of the Intergovernmental Panel on Climate Change (p. 151). Geneva, Switzerland: IPCC.

Petit, G., Anfodillo, T., Carraro, V., Grani, F., \& Carrer, M. (2011). Hydraulic constraints limitheight growth in trees athighaltitude. New Phytologist, 189(1), 241-252. https://doi.org/10.1111/j.1469-8137.2010.03455.x

Pfautsch, S., Harbusch, M., Wesolowski, A., Smith, R., Macfarlane, C., Tjoelker, M. G., ... Adams, M. A. (2016). Climate determines vascular traits in the ecologically diverse genus Eucalyptus. Ecology Letters, 19(3), 240-248. https://doi.org/10.1111/ele.12559

Pittermann, J., \& Sperry, J. (2003). Tracheid diameter is the key trait determining the extent of freezing-induced embolism in conifers. 
Tree Physiology, 23(13), 907-914. https://doi.org/10.1093/treep hys/23.13.907

Pittermann, J., \& Sperry, J. S. (2006). Analysis of freeze-thaw embolism in conifers. The interaction between cavitation pressure and tracheid size. Plant Physiology, 140(1), 374-382. https://doi.org/10.1104/ pp.105.067900

Pockman, W. T., \& Sperry, J. S. (2000). Vulnerability to xylem cavitation and the distribution of Sonoran desert vegetation. American Journal of Botany, 87(9), 1287-1299. https://doi.org/10.2307/2656722

Poorter, L., McDonald, I., Alarcón, A., Fichtler, E., Licona, J.-C., PeñaClaros, M., ... Sass-Klaassen, U. (2010). The importance of wood traits and hydraulic conductance for the performance and life history strategies of 42 rainforest tree species. New Phytologist, 185(2), 481-492. https://doi.org/10.1111/j.1469-8137.2009.03092.x

Prentice, I. C., Bondeau, A., Cramer, W., Harrison, S. P., Hickler, T., Lucht, W., ... Sykes, M. T. (2007). Dynamic global vegetation modeling: Quantifying terrestrial ecosystem responses to large-scale environmental change. In J. G. Canadell, D. E. Pataki, \& L. F. Pitelka (Eds.), Terrestrial ecosystems in a changing world (pp. 175-192). Berlin, Heidelberg: Springer.

Putnam, A. E., \& Broecker, W. S. (2017). Human-induced changes in the distribution of rainfall. Science Advances, 3(5), e1600871. https://doi. org/10.1126/sciadv.1600871

R Core Team. (2018). $R$ : A language and environment for statistical computing. Retrieved from https://www.R-project.org/

Reich, P. B., Ellsworth, D. S., Walters, M. B., Vose, J. M., Gresham, C., Volin, J. C., \& Bowman, W. D. (1999). Generality of leaf trait relationships: A test across six biomes. Ecology, 80(6), 1955-1969. https://doi. org/10.1890/0012-9658(1999)080[1955:GOLTRA]2.0.CO;2

Sakai, A., \& Weiser, C. J. (1973). Freezing resistance of trees in North America with reference to tree regions. Ecology, 54(1), 118-126. https://doi.org/10.2307/1934380

Santiago, L. S., Goldstein, G., Meinzer, F. C., Fisher, J. B., Machado, K., Woodruff, D., \& Jones, T. (2004). Leaf photosynthetic traits scale with hydraulic conductivity and wood density in Panamanian forest canopy trees. Oecologia, 140(4), 543-550. https://doi.org/10.1007/ s00442-004-1624-1

Shao, J., Yuan, T., Li, Z., Li, N., Liu, H., Bai, S. H., ... Zhou, X. (2019). Plant evolutionary history mainly explains the variance in biomass responses to climate warming at a global scale. New Phytologist, 222(3), 1338-1351. https://doi.org/10.1111/nph.15695

Sperry, J. S., Donnelly, J. R., \& Tyree, M. T. (1988). A method for measuring hydraulic conductivity and embolism inxylem. Plant, Cell\& Environment, 11(1), 35-40. https://doi.org/10.1111/j.1365-3040.1988.tb01774.x

Sperry, J. S., Hacke, U. G., \& Pittermann, J. (2006). Size and function in conifer tracheids and angiosperm vessels. American Journal of Botany, 93(10), 1490-1500. https://doi.org/10.3732/ajb.93.10.1490

van der Sande, M. T., Poorter, L., Schnitzer, S. A., Engelbrecht, B. M., \& Markesteijn, L. (2019). The hydraulic efficiency-safety trade-off differs between lianas and trees. Ecology, 100(5), e02666. https://doi. org/10.1002/ecy.2666

Wang, Z., Fang, J., Tang, Z., \& Lin, X. (2010). Patterns, determinants and models of woody plant diversity in China. Proceedings of the Royal Society B: Biological Sciences, 278(1715), 2122-2132. https://doi. org/10.1098/rspb.2010.1897

Woodward, F. I. (1990). The impact of low temperatures in controlling the geographical distribution of plants. Philosophical Transactions of the Royal Society of London. B, Biological Sciences, 326(1237), 585593. https://doi.org/10.1098/rstb.1990.0033

Wright, I. J., Dong, N., Maire, V., Prentice, I. C., Westoby, M., Díaz, S., ... Leishman, M. R. (2017). Global climatic drivers of leaf size. Science, 357(6354), 917-921. https://doi.org/10.1126/science.aal4760
Wright, I. J., Reich, P. B., Cornelissen, J. H. C., Falster, D. S., Garnier, E., Hikosaka, K., ... Westoby, M. (2005). Assessing the generality of global leaf trait relationships. New Phytologist, 166(2), 485-496. https:// doi.org/10.1111/j.1469-8137.2005.01349.x

Wright, I. J., Reich, P. B., Westoby, M., Ackerly, D. D., Baruch, Z., Bongers, F., ... Villar, R. (2004). The worldwide leaf economics spectrum. Nature, 428(6985), 821-827. https://doi.org/10.1038/ nature 02403

Xu, X., Medvigy, D., Powers, J. S., Becknell, J. M., \& Guan, K. (2016). Diversity in plant hydraulic traits explains seasonal and inter-annual variations of vegetation dynamics in seasonally dry tropical forests. New Phytologist, 212(1), 80-95. https://doi.org/10.1111/ nph.14009

Yuan, W., Liu, S., Yu, G., Bonnefond, J.-M., Chen, J., Davis, K., ... Verma, S. B. (2010). Global estimates of evapotranspiration and gross primary production based on MODIS and global meteorology data. Remote Sensing of Environment, 114(7), 1416-1431. https://doi. org/10.1016/j.rse.2010.01.022

Zanne, A. E., Westoby, M., Falster, D. S., Ackerly, D. D., Loarie, S. R., Arnold, S. E., \& Coomes, D. A. (2010). Angiosperm wood structure: Global patterns in vessel anatomy and their relation to wood density and potential conductivity. American Journal of Botany, 97(2), 207215. https://doi.org/10.3732/ajb.0900178

Zhang, J., Gou, X., Manzanedo, R. D., Zhang, F., \& Pederson, N. (2018). Cambial phenology and xylogenesis of Juniperus przewalskii over a climatic gradient is influenced by both temperature and drought. Agricultural and Forest Meteorology, 260, 165-175. https://doi. org/10.1016/j.agrformet.2018.06.011

Zhang, S. B., Cao, K. F., Fan, Z. X., \& Zhang, J. L. (2013). Potential hydraulic efficiency in angiosperm trees increases with growth-site temperature but has no trade-off with mechanical strength. Global Ecology and Biogeography, 22(8), 971-981. https://doi.org/10.1111/ geb.12056

Zhou, S., Duursma, R. A., Medlyn, B. E., Kelly, J. W., \& Prentice, I. C. (2013). How should we model plant responses to drought? An analysis of stomatal and non-stomatal responses to water stress. Agricultural and Forest Meteorology, 182, 204-214. https://doi.org/10.1016/ j.agrformet.2013.05.009

Zhu, S. D., Song, J. J., Li, R. H., \& Ye, Q. (2013). Plant hydraulics and photosynthesis of 34 woody species from different successional stages of subtropical forests. Plant, Cell \& Environment, 36(4), 879-891. https:// doi.org/10.1111/pce.12024

Zomer, R. J., Trabucco, A., Bossio, D. A., \& Verchot, L. V. (2008). Climate change mitigation: A spatial analysis of global land suitability for clean development mechanism afforestation and reforestation. Agriculture, Ecosystems \& Environment, 126(1-2), 67-80. https://doi. org/10.1016/j.agee.2008.01.014

\section{SUPPORTING INFORMATION}

Additional supporting information may be found online in the Supporting Information section.

How to cite this article: He P, Gleason SM, Wright IJ, et al. Growing-season temperature and precipitation are independent drivers of global variation in xylem hydraulic conductivity. Glob Change Biol. 2020;26:1833-1841. https:// doi.org/10.1111/gcb.14929 